\title{
China rising - strategies and tactics of China's growing presence in the world: a special issue of RBPI
}

\author{
China em ascensão - estratégias e táticas da crescente \\ presença da China no mundo: uma edição especial da RBPI
}

http://dx.doi.org/10.1590/0034-7329201400201

HENRIQUE ALTEMANI DE OLIVEIRA*

ANTÔNIO CARLOS LESSA**

Rev. Bras. Polít. Int. 57 (special edition): 5-8 [2014]

In 2014 it will have passed 40 years since diplomatic relations were established between Brazil and the People's Republic of China. Under a dictatorial regime and with opposition from the most radical sectors of the Armed Forces, the decision of the Brazilian government was triggered by the consideration that the approximation to China was fundamental for the role that Brazil played, towards the Third World, in the negotiation process for defining a New International Economic Order. With a much more political than economic-commercial emphasis, one would never think at that time that China would become such an economic power.

In that sense, the Brazilian Journal of International Politics (RBPI) deemed as opportune to release a special edition on China, not only to celebrate the double acknowledgement in 1974 that turned into the first strategic partnership proposed by China in 1993, but mostly to seek a deeper reflection on the Chinese strategies and tactics to its growing international presence.

Considering the already-existent, extensive quality literature on the Chinese economic and commercial insertion, this special edition sought to assess prioritarily the current state of that country's presence in the International System and its institutions, and its relations with main powers, with regions, and with regional powers, emphasizing the political and diplomatic aspects.

Nowadays it is a consensus that China acquired a relevance that was unimaginable forty years ago. It is a new phase corresponding to the perceived existence of a consensual international recognition that China has reached a level

\footnotetext{
* State University of Paraíba (UEPB), Campina Grande, PB, Brazil (henrique.altemani@gmail.com).

** Institute of International Relations, University of Brasília (UnB), Brasília, DF, Brazil (aclessa@gmail.com).
} 
of power that empowers it to take on a much more assertive role than the one it played before. Furthermore, China not only is empowered but also shows to be, in this decade, acting much more assertively.

Starting from the principle that the United States still represent the ultima ratio in the International System, their leadership being fundamental for any kind of collective action in the International System, different analysts ponder that the American action is based on promoting democracy and freedom from markets, though mixing their own interests with global interests.

In consequence of limited resources and mostly due to the North American public opinion opposing interventions where its interests are not directly involved, the United States seek to reinforce a greater participation of different players, through sharing burdens and reinforcing the perspective of widespread practices of engagement and expansion, instead of the containment policy used during the Cold War.

The engagement and expansion policy showed two perspectives. In the first, the participation of the United States in any question that directly affected their security or the political balance in regions deemed strategic, as well as the commercial flows. In the other perspective, there was the need for greater participation of different players that benefitted both from the safe environment and the economic globalization.

Nevertheless, in what concerns the relation with China, in the end of the last century and in the beginning of this century, the United States oscillated between strategies of engagement and containment, due to either widened or reduced perception of China as a threat.

This "Theory of Threat" clearly has two dimensions: the strategic security one and the economic one. In the dimension of security, the most relevant are the considerations of an arms race strategy, irresponsible arms sale or military technologies transfer and the presence of historical conflicts and territorial revindications in its close surroundings. Under another perspective, there is also a reflection that this theory of threat is due to a widespread perception that China is already in conditions to take a more active role in regional and international issues-in that sense, the perception that China, by expanding its space, is necessarily dislocating or reducing the capacities of other players. For China, in its turn, the America factor is still important, however much less significant that it was in the 1990s. First, due to the fact that the power balance between China and the United States has changed - the United States are still a power, bur China is growing much stronger, with diverse interests in the whole world.

Second, the international power structure is in process of changes, with new players rising and/or factors the American influence.

Third, China has developed a new pattern of interest, especially in commercial terms, and works with multiple partners, including the European Union, the United States, Japan, and ASEAN. Since the US influence on China's diplomatic 
strategy has reduced, the status of other countries and regions tends to increase. Lastly, since China and the United States have become incredibly interdependent, they must act jointly and display a more stable relationship.

Thus, while it manages its relationship with the major powers (US, Russia, and the European Union), China has strengthened its strategic relations with Latin America, Africa, and the Middle East by establishing cooperation forums, and has changed the strategy of its presence in Asia. Even though these regions share (or not) a common lack of fear, each relationship with China is distinct.

For many analysts, regional strategies derive from China's global grand strategy, often called "peaceful rise," with emphasis on at least four dimensions: political-diplomatic, security, commercial, and cultural. For some analysts, this "peaceful rise" represents a "pragmatic choice."

In summary, current China is not only an economic giant; it is also modernizing its military, is a member of the main regional and international institutions, and is intensively visible in international politics.

The basic message of the Chinese rhetoric of harmonic development is the need for different actors to acknowledge not only the Chinese entitlement to development, but also the fact that China is growing and this must be, harmonically, accepted by the International System so as to assure an environment of peace, development, and cooperation. In this sense, the principle of "noninterference in internal issues" should be respected more and the international relationship should be supported in the perspective of mutual interests and "pacific coexistence." In the internal scope, the fact that fast, localized development generates distortions that will need to be harmonically corrected to encompass the whole of the Chinese society.

The United States, however, do not work anymore with the duality between engaging with or containing China. Starting with the acknowledgement of the great economic, political, and strategic expression that China has taken, the US currently aims to contain the Chinese growth, or rather to counterbalance its capacities. In that sense, the launchings of the "pivot for Asia," as well as of the Trans-Pacific Partnership (TPP) and of the Transatlantic Trade and Investment Partnership (TTIP), are initiatives with the clear goal of limiting the Chinese capacities in the political-strategic and economic dimensions.

Even though it has relative greater importance in this anti-China strategy for directly encompassing the Asian region, the TPP apparently does not advance, due to the divergences between Japan and the US concerning the trade in agricultural and automotive goods, and mostly due to the Congress not having yet granted a negotiating mandate to the Obama administration. And will the TTIP, in order to advance, manage to break the rigidity of the EU's Common Agricultural Policy?

In the same fashion, the American pivot appears to equally stall. First, the United States have not to date obtained funding to military investments in Asia and, in practice, have redistributed troops and primordially seeks to convince 
Asian countries - especially Japan - to take greater participation in maintaining Asian security. In that sense, with no perspective of the resolution of the territorial disputes in the South China Sea and of the Chinese-Japanese dispute concerning the Diaoyu/Senkaku islands, the environment seems to aggravate with the Chinese declaration of an Air Defense Identification Zone (ADIZ) in the East China Sea and with the beginning of drillings, in May 2014, by the China National Overseas Oil Corporation (CNOOC) in the Paracel Islands, in a space claimed by Vietnam.

The US government position of not taking sides in the Paracel Islands dispute and declaring that the parties involved should seek a pacific solution to their divergences leaves the impression that the United States has difficulties in imposing their interests. Or, in the other hand, China-with its political, economic, and strategic interdependences-already displays a relevance that curtails the possibilities of more effective actions by the United States.

In brief, all of this indicates that the redefinition process of the International System has reached a point in which it has a strong candidate disputing the international power. However, it is a player that, despite its greater relevance and large capabilities, still has deep internal and external fragilities, which do not allow for more affirmative forecasts, neither in the short, nor in the medium term.

This way, there is much to be analyzed concerning China, what it wants and how different actors react and will react to the change of roles in the redefinition of the International System and Order. In that sense, this special edition of RBPI seeks to cast light on the central aspects of the international rising of China, and it can be read as an important contribution to the reflection made on the Global South on this subject.

This special edition is aligned with a series of thematic editions on thoughtprovoking subjects in the contemporary international agenda, and also on the international insertion of Brazil we have been preparing throughout the last few years, all of them published in English, counting with the growing participation of highly-qualified international scholars. This edition has yet further particular meaning - it is fruit of the cooperation of the Brazilian Institute of International Relations, which publishes this journal, with the Center for Studies on the Pacific, a Brazilian organization which pioneers in high-level reflections on the developing reality of Asia and on its consequences to the whole world. We feel particularly accomplished with the extraordinarily high number of contributions received for this edition, and we thank all the researchers who took their time to collaborate in this endeavor. We are also pleased with the diversity of works that compose this edition, which we hand to our readers, who we expect will echo with us the quality of the studies hereby gathered. 